\title{
SIX SPECIES OF THE SUBFAMILY CYTHERURINAE MULLER, 1894, IN THE INLAND SEA, JAPAN (OSTRACODA)
}

\author{
$\operatorname{AUTHOR(S):~}$
}

Okubo, Ichiro

\section{CITATION:}

Okubo, Ichiro. SIX SPECIES OF THE SUBFAMILY CYTHERURINAE MULLER, 1894, IN THE INLAND SEA, JAPAN (OSTRACODA). PUBLICATIONS OF THE SETO MARINE BIOLOGICAL LABORATORY 1980, 25(1-4): 7-26

\section{ISSUE DATE:}

1980-02-29

URL:

http://hdl.handle.net/2433/175996

RIGHT: 


\title{
SIX SPEGIES OF THE SUBFAMILY GYTHERURINAE MÜLLER, 1894, IN THE INLAND SEA, JAPAN (OSTRACODA) ${ }^{1,2}$ )
}

\author{
IaHIRO OKUBO \\ Okayama Shujitsu Junior College \\ With Text-figures $1-10$
}

This paper deals with six species of the subfamily Cytherurinae Müller, 1894, in the Inland Sea: viz., three Hemicytherura and three Semicytherura species, with special reference to the description of two new semicytherure species and appendages of hemicytherure and semicytherure species.

As regards Hemicytherura, three recent species have hitherto been reported from Japan, which also occur in the Inland Sea.

Semicytherura is established by Wagner (1957) for cytherure species possessing the conspicuously wide infold and fused zone, and the crenulate median hinge-element. Hanai (1957), scrutinizing valves of Japanese Semicytherura (then, a part of Cytherura) species, has indicated that they may be divided into at least two groups: namely, the second group of Müller (1894) represented by $S$. miurensis and a new group characterized by thick valves with undulated ridges, comprising $S$. henryhowei $(=C$. quadrata, then). Examining semicytherure species in the Inland Sea reveals that two groups are different also in appendages. The groups are named miurensis-group and henryhowei-group and described here.

I wish to express my thanks to Prof. A. Inaba of Hiroshima University and Prof. T. Hanai of the University of Tokyo for their invaluable advice.

\section{Material and Station Data}

Specimens examined have been collected in intertidal zones of the following coasts in the middle area of the Inland Sea.

(D) Desaki peninsula, Tamano-shi, $\left(133^{\circ} 59.8^{\prime} \mathrm{E}, 34^{\circ} 30.9^{\prime} \mathrm{N}\right)$, on various days, date supplemented.

(HSB) Hosonosu sand bank $\left(133^{\circ} 8.0^{\prime} \mathrm{E}, 34^{\circ} 21.9^{\prime} \mathrm{N}\right), 17-\mathrm{VII}-1977$.

(O) Ohama, Kurashiki-shi, (133 $\left.49.5^{\prime} \mathrm{E}, 34^{\circ} 30.9^{\prime} \mathrm{N}\right)$, 2-VII-1977.

(M) Muneage, Toji-cho, $\left(134^{\circ} 1.5^{\prime} \mathrm{E}, 34^{\circ} 32.5^{\prime} \mathrm{N}\right), 16-\mathrm{VI}-1976$.

1) Recent Marine Ostracoda in the Inland Sea, Japan-XV.

2) Contribution from the Mukaishima Marine Biological Station, No. 173.

Publ. Seto Mar. Biol. Lab., XXV(1/4), 7-26, $1980 . \quad$ (Article 2) 
(MBS) Mukaishima Marine Biological Station $\left(133^{\circ} 13.2^{\prime} \mathrm{E}, 34^{\circ} 21.7^{\prime} \mathrm{N}\right)$, on various days, date supplemented.

(MI) Maejima Island (134 $\left.10.4^{\prime} \mathrm{E}, 34^{\circ} 36.0^{\prime} \mathrm{N}\right)$, 7-VIII-1976.

(SI) Shijushima Islet $\left(133^{\circ} 9.9^{\prime} \mathrm{E}, 34^{\circ} 21.5^{\prime} \mathrm{N}\right), 18-\mathrm{VII}-1977$.

(Capitals in parentheses are symbols of Stations.) HSB, MBS, SI in Hiroshima Pref., the others in Okayama Pref.

In the Material column of each species, [MO-provisional No., Sex, Left, Right valve (length-height) or $\mathrm{C}$ (length-width) in $0.01 \mathrm{~mm}$, Symbol of Station] is to be
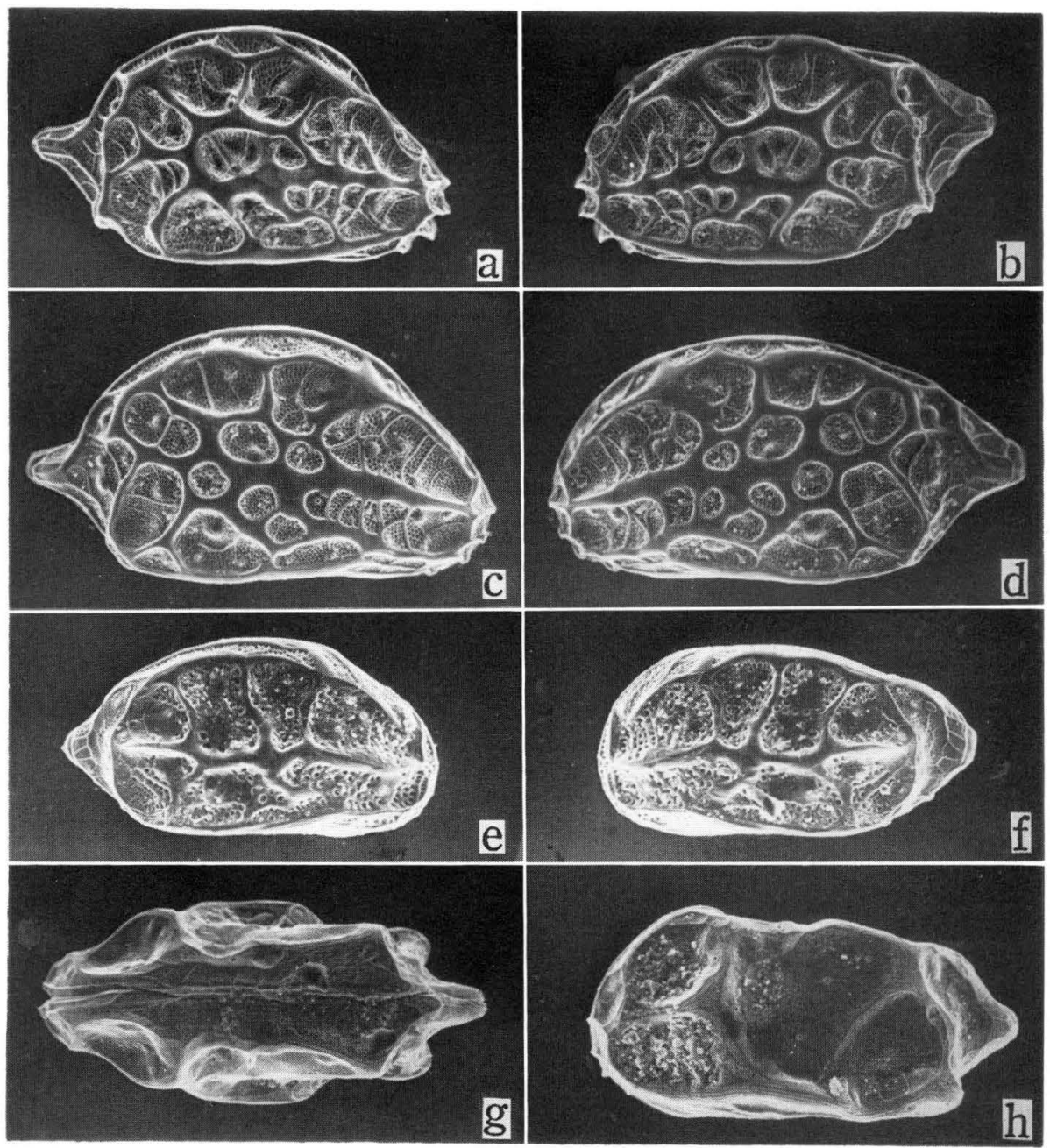

Fig. 1. Hemicytherura \& Semicytherura (SEM photo, ca $\times 100$ ).

a, b, H. cuneata (MO-1102, 우); c, d, H. kaiiyamai (MO-1097, 우); e, f, H. tricarinata (MO-1096, 우); $\mathrm{g}, \mathrm{h}, \mathrm{S}$. henryhowei (g, MO-1101, ?; h, MO-1100, ㅇ).

a, c, e, right valve; b, d, f, h, left valve; $\mathrm{g}$, carapace (from dorsal).

The scanning electron microscope photographs were taken at the Paleontological Laboratory, Geological Institute, Faculty of Science, University of Tokyo. 


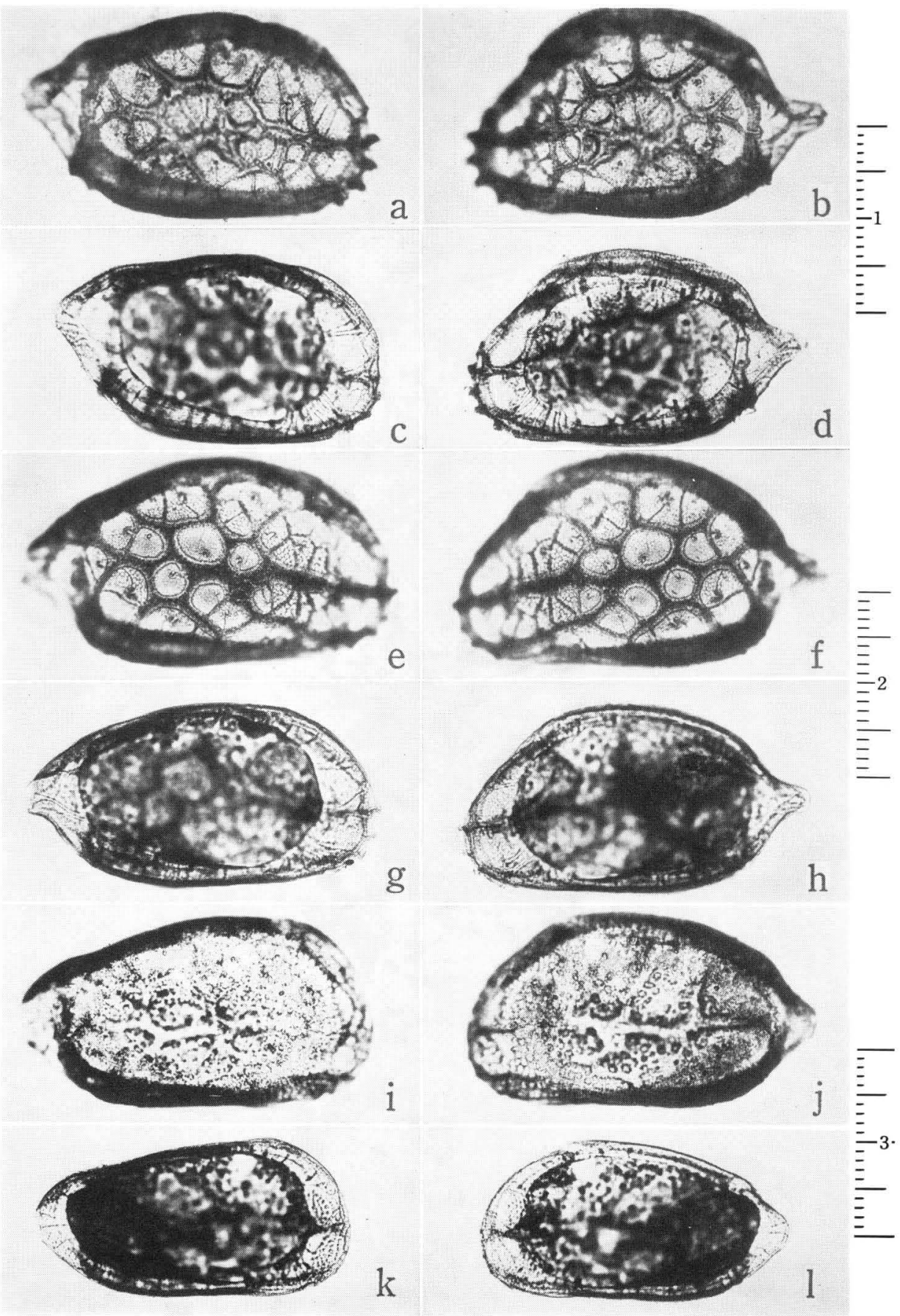

Fig. 2. Hemicytherura.

a-d, H. cuneata; a, b, MO-790, o; c, d, MO-773, o7. e-h, H. kajizamai; e, f, MO-874, if; g, h,

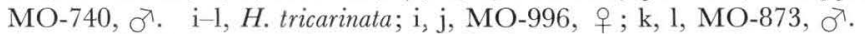

(a, b, e, f, i, j, focussed on lateral wall; the others on margins).

Scales given in $0.2 \mathrm{~mm}$ : 1 for a- $\mathrm{d}, 2$ for $\mathrm{e}-\mathrm{h}, 3$ for $\mathrm{i}-\mathrm{l}$. 

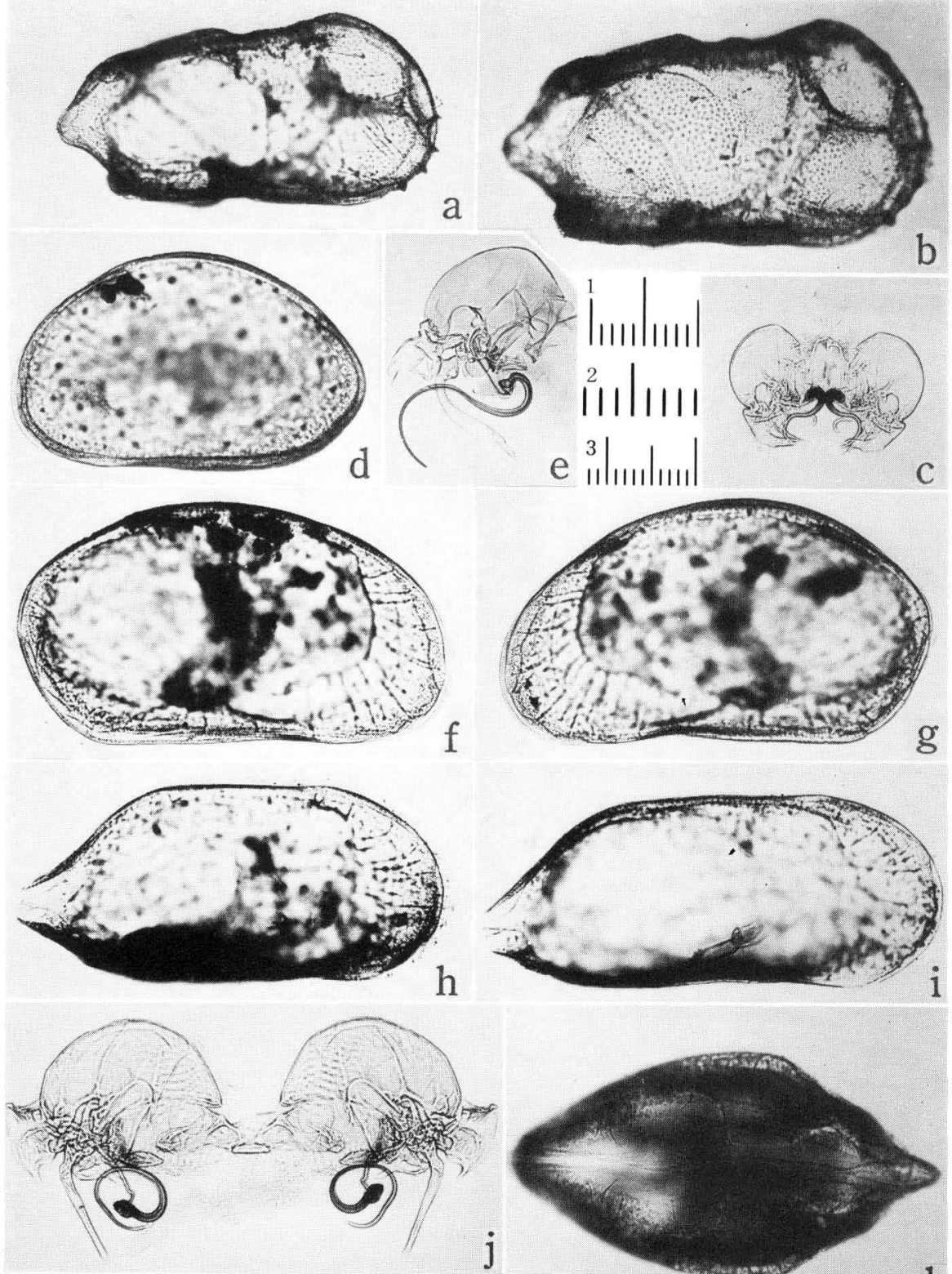

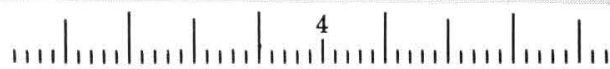

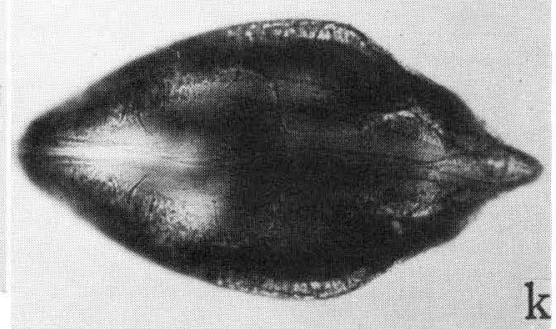

Fig. 3. Semicytherura.

a-c, S. henryhowei; a, MO-772, ơ; b, MO-678, 우; c, MO-788, ○`. d-g, S. hiberna; d, MO-991, A-1; e- g, MO-990, o․ h-k, S. mukaishimensis; h, MO-571, 우; i, j, MO-561, o․ k, MO-563, 우. $\mathrm{a}, \mathrm{b}, \mathrm{f}, \mathrm{h}, \mathrm{i}$, left valve; d, g, right valve; c, e, j, copulatory organ (a, b, focussed on lateral wall, $d, f-i$, on margins).

Scale: $1(=0.1 \mathrm{~mm})$ for $\mathrm{a}, \mathrm{b} ; 2(=0.07 \mathrm{~mm})$ for $\mathrm{c} ; 3(=0.12 \mathrm{~mm})$ for $\mathrm{d}-\mathrm{g} ; 4(=0.46 \mathrm{~mm})$ for $\mathrm{h}-\mathrm{k}$. 
written. The specimens are dissected and embedded in Canada balsam (valves) and in Neo-Shigaral (soft parts). The holotypes and allotypes and some of paratypes will be deposited in the National Science Museum, Tokyo, and some of paratypes in the Mukaishima Marine Biological Station, Hiroshima University.

Family Cytheruridae Müller, 1894

Subfamily Cytherurinae Müller, 1894

Genus Hemicytherura Elofson, 1941

Type-species: Cythere cellulosa Norman, 1865

Description. Male smaller and lower than female; however, little difference occurring in sculpture of valves. Surface finely or coarsely reticulated. Inside of valve, when alive, usually covered with blackish or brownish pigments.

Left and right valves of great asymmetry; right valve higher than, and overhanging along dorsal margin, the left. Valves small, more or less calcified, sub-rhomboidal or triangular, with prominent caudal process, and usually with denticles or tubercles along anterior margin.

Infold rather wide, sub-equal in width to fused zone; small vestibule often existent. Radial pore canals small to moderate in number, unbranched, showing a tendency to group; a few false radial pore canals present. Normal pore canals scattered. Hingement merodont, of arched type (Hanai, 1957). Adductor muscle scars four in vertical row, with one anterior scar, but in some species obscure.

Antennula: Of six podomeres; rather slender. First podomere without seta. Second podomere with seta postero-medially. Third podomere with seta anterodistally. Fourth and fifth podomeres with two setae antero-distally, one seta posterodistally, respectively. Sixth podomere with three setae and sense club distally.

Antenna: Of five podomeres. First podomere without seta. Second podomere stout, with two setae postero-distally. Third podomere tapering, with two setae postero-distally. Fourth podomere long, with respective one seta proximally, posterodistally and on antero-medial setiferous ledge. Fifth podomere with two claws. Spinneret seta three- or four-segmented; kneeling at penultimate joint.

Mandible: Coxa rather large. Palp indistinctly four-segmented. First podomere of palp with seta postero-distally, and with exopodite of one large plumose seta. Second podomere with one seta antero-distally, three setae postero-distally. Third podomere with four setae antero-medially, two setae postero-distally, one stout seta distally. Fourth podomere with three stout setae distally.

Maxillula: Branchial plate with about 15 feather-like setae, two vibratory setae of equal length. Palp of two podomeres; proximal one long, with four setae anterodistally; distal one rather small, with three setae distally, one seta postero-medially. Outer, middle, inner masticatory lobe provided with six, six, four setae, respectively.

Walking legs: Of four podomeres; protopodite comparatively small, second to fourth podomeres rather slender; setal formula for (antero-medial, antero-distal, pos- 
terior) areas of porotpodites of maxilla, thoracopoda $1 \& 2:(1,2,2),(1+1,1,2)$, $(0,1,0)$; second podomeres with setae antero-distally; claws rather large.

Copulatory organ: Basal part large, with two processes of various shapes and short copulatory tube.

(The above generic description is mostly based on data obtained from Japanese species.)

\section{Hemicytherura cuneata Hanai, 1957}

(Figs. 1a, b; 2a-d; 4)

Hemicytherura cuneata Hanai, 1957, p. 24, Pl. 2, figs. 2a, b, text-figs. la, b, Japan (Kanagawa Pref.); 1961, p. 358, text-fig. 2, figs. 1a, b; Ishizaki, 1966, p. 140, Pl. 18, figs. 22, 23, Japan (Miyagi Pref., Miocene); ——, 1968, p. 20, Pl. 4, fig. 18, Japan (Kochi Pref.); Hanai et al., 1977, p. 55.

Description. Valves small, thick, of great asymmetry. Left valve ovate; greatest height just in front of the middle. Dorsal margin slightly arched, descending backwards. Anterior margin obliquely rounded, with four denticles in lower half. Posterior margin triangularly protruding; the extremity at three-fifths height. Ventral margin almost straight.

Right valve sub-rhomboidal, with prominent dorsal hump; therefore, anterodorsal concave formed, and caudal process more remarkable; devoid of hump, both valves resembling in outline to each other.

Male a little smaller and slightly lower than female.

Surface ornamented with ridges and reticulated hollows. Hollows composed of one central and eight peripheral ones; central one elliptical, subdivided into four; two anterior ones elongate, subdivided into several. From strong ring-like ridge surrounding central hollow, eight ridges radiating to marginal ridges. Anterior marginal ridge rather weak, sub-peripheral; dorsal one sinuate; ventral one on ventral margin; posterior one sinuate, apart from posterior end, forming sharp angle posteroventrally.

Infold and fused zone moderate in width. Vestibule very narrow. Inner margin smooth. Radial pore canals about 20 in number, with a few false radial pore canals, showing a tendency to be grouped. Line of concrescence rather irregular near midventral margin. Normal pore canals scattered. Adductor muscle scars obscure. Hingement merodont, of arched type.

Antennula: Distal five podomeres having length ratio $14: 13: 16: 15: 4$ in a female, 14:14:16:16:5 in a male, along posterior chitinous margins towards distal end. Antenna: Distal four podomeres and claw having length ratio $11: 14: 9+15: 5: 17$ in a female, 10:13:10+14:5:18 in a male, along anterior chitinous margins. Spinneret seta threesegmented at length ratio of $46: 12: 11$ in a female, $44: 10: 10$ in a male, forming knee at proximal joint.

Mandible and Maxillula: Of hemicytherure type.

Walking legs: Length ratio of second to fourth podomeres and claws of maxilla, thoracopoda 1 \& $2,(18: 10: 12: 18)$ or $(12: 7: 8: 15):(25: 13: 15: 22):(33: 12: 17: 24)$ in a 

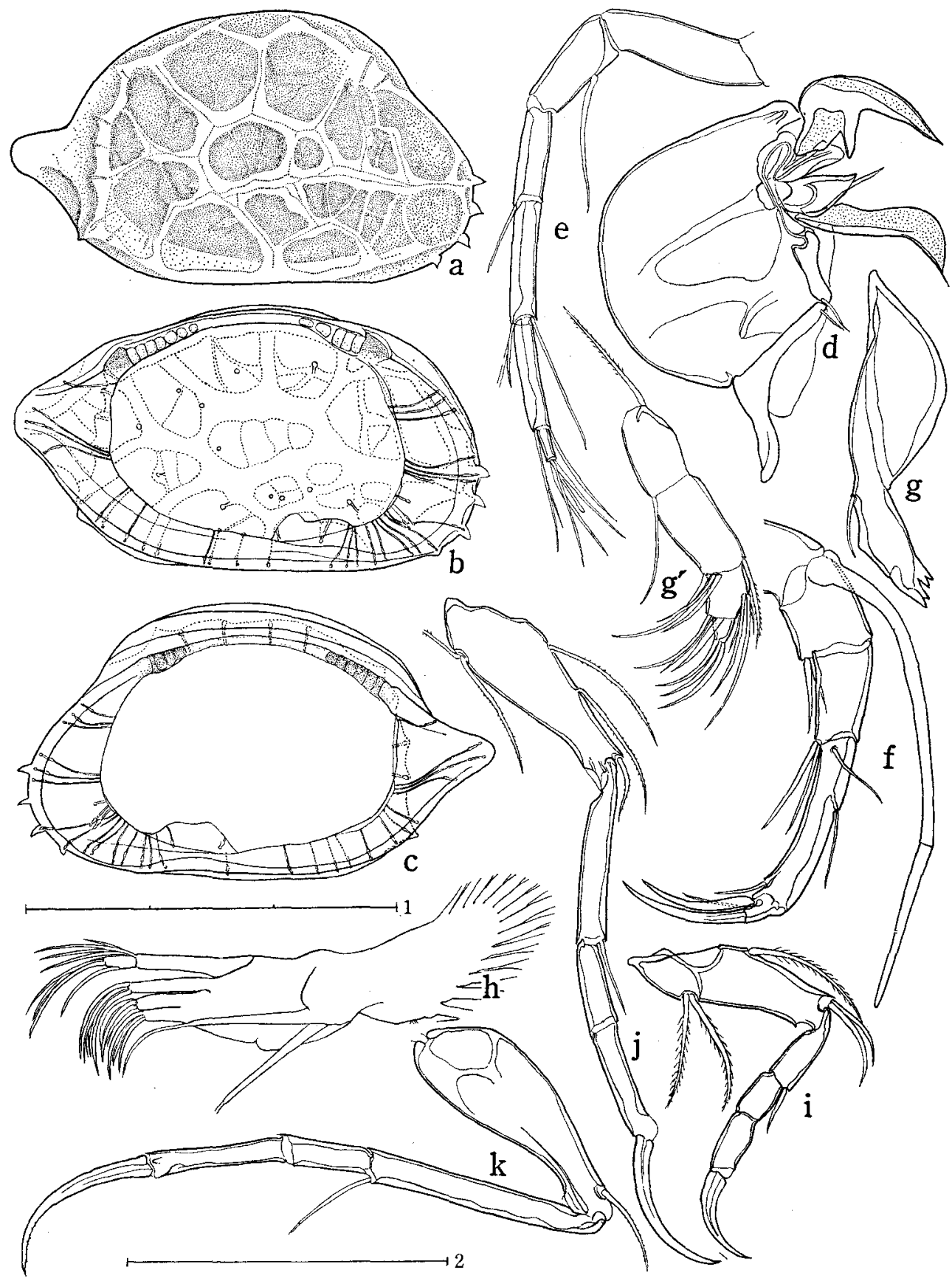

Fig. 4. Hemicytherura cuneata.

a-c, 우 (MO-696); d, o (MO-773); e-k, 우 (MO-781); g', 우 (MO-787).

$a$, right valve (outside); b, left valve; $c$, right valve; $d$, copulatory organ; $e$, antennula; $f$, antenna; $g, g^{\prime}$, mandible; $h$, maxillula; $i$, maxilla; $\mathbf{j}$, thoracopoda $1 ; \mathrm{k}$, thoracopoda 2.

Scale: $1(=0.3 \mathrm{~mm})$ for $\mathrm{a}-\mathrm{c} ; 2(=0.1 \mathrm{~mm})$ for $\mathrm{d}-\mathrm{k}, \mathrm{g}^{\prime}$. 
female, $(18: 10: 13: 19):(24: 12: 15: 23):(33: 12: 17: 24)$ in a male, along posterior margins; one maxilla of female atrophied in some specimens.

Copulatory organ: Basal part elliptical, with two flame-shaped lamellar processes and small triangular copulatory tube.

(Other characters : cf. generic description.)

Material. MO-773, ơ, LV (36-21), RV (37-21), SI. MO-781, ㅇ, LV (38-22), RV (38-22), SI. MO-790, ㅇ, LV (39-22), RV (39-23), SI. MO-696, ㅇ, LV (39-22), RV (39-23), O.

Occurrence. Rather rare, in intertidal zones of rocky shores; not found in sand banks where $H$. kajiyamai occurs abundantly.

Remarks. Specimens in the Inland Sea agree with Hanai's (1957). This species resembles $H$. kajiyamai, but differs from it in the sculpture of valves; in the present species the central hollow is large, elliptical, and subdivided into four, and also posteroventrally the posterior marginal ridge makes an acute angle, which prominently projects beyond the outline.

Little sexual dimorphism is found in appendages, except for one maxilla in some females.

\section{Hemicytherura kajiyamai Hanai, 1957}

(Figs. 1c, d; 2e-h, 5)

Cytheropteron videns Müller, Kajiyama, 1913, p. 4, Pl. 1, figs. 19-25, Japan (Kanagawa Pref.).

Hemicytherura kajiyamai Hanai, 1957, p. 24, Pl. 2, figs. 1a-d, Japan (Kanagawa Pref; Gifu Pref., Miocene); - , 1959, p. 430; Hanai et al., 1977, p. 55.

Not Cytheropteron videns Müller, 1894.

Description. Valves small, thick, of great asymmetry. Left valve ovate; greatest height just in front of the middle. Dorsal margin arched evenly, slightly descending backwards. Anterior margin rounded obliquely, with four denticles. Posterior margin triangularly protruding; upper half slightly convex, middle end truncate, lower half concave. Ventral margin nearly straight. Right valve higher than, and overhanging the left, owing to dorsal hump; antero- and postero-dorsal margins concave. Male smaller and lower than female.

Surface adorned with ridges and reticulated hollows. Central hollows small, four in number; upper one just above centre, slightly larger than the others; lower one connecting with antero-ventral peripheral hollow. Peripheral hollows large; two anterior ones elongate, subdivided into several. Posterior marginal ridge greatly sinuate, apart from posterior margin, making obtuse angle with ventral ones posteroventrally; anterior one weak; dorsal one sinuate. Longitudinal ridge strong, from upper anterior denticle through between central hollows to postero-dorsal margin.

Marginal zone resembling in $H$. cuneata. Infold and fused zone moderate in width, slightly wider anteriorly and posteriorly. Vestibule narrow anteriorly, rather wide postero-ventrally. Radial pore canals moderate in number, with a few false radial 


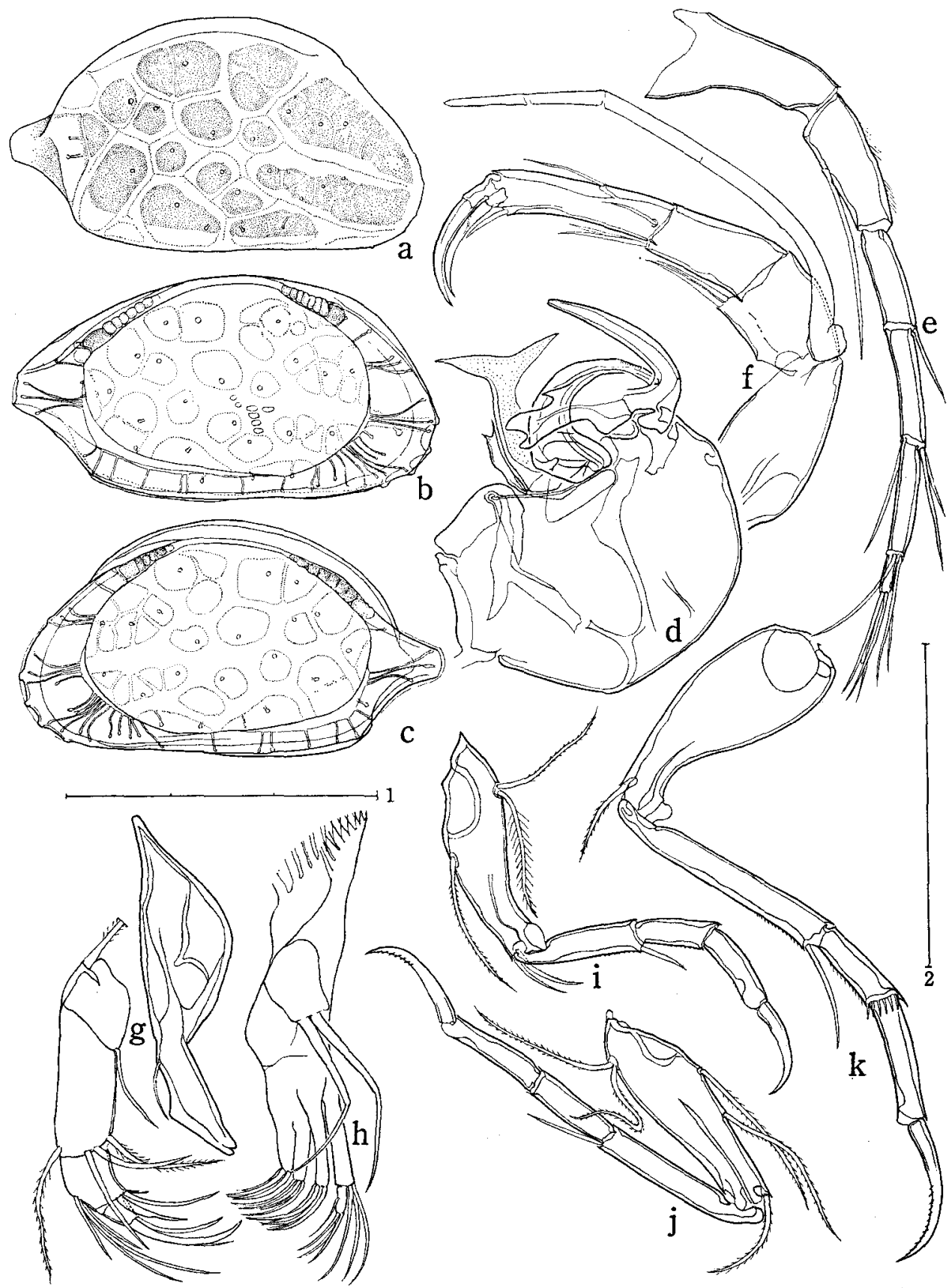

Fig. 5. Hemicytherura kajiyamai.

$\mathrm{a}-\mathrm{c}, \mathrm{e}-\mathrm{g}, \mathrm{i}-\mathrm{k}$, 우 (MO-874); d, o (MO-740); h, 이 (MO-874').

a, right valve (outside); b, left valve; c, right valve; $d$, copulatory organ; e, antennula; f, antenna; $\mathrm{g}$, mandible; $\mathrm{h}$, maxillula; $\mathrm{i}$, maxilla; $\mathrm{j}$, thoracopoda $1 ; \mathrm{k}$, thoracopoda 2 . Scale: $1(=0.3 \mathrm{~mm})$ for $\mathrm{a}-\mathrm{c} ; 2(=0.1 \mathrm{~mm})$ for $\mathrm{d}-\mathrm{k}$. 
pore canals, tending to group into three anteriorly, one posteriorly. Adductor muscle scars small.

Antennula: Distal five podomeres having length ratio 19:14:15:15:4 in a female, 18:13:15:16:5 in a male. Antenna: Distal four podomeres and claw having length ratio $14: 15: 9+14: 5: 15$ in a female, $13: 14: 8+15: 4: 15$ in a male. Spinneret seta three-segmented at length ratio $50: 10: 11$ in a female, 47:9:10 in a male; proximal joint forming knee.

Mandible and Maxillula: Of hemicytherure type.

Walking legs: Length ratio of second to fourth podomeres and claws having length ratio $(16: 10: 11: 14):(23: 12: 13: 14):(32: 13: 17: 21)$ in a female, $(15: 10: 10: 12):(21: 13$ : $13: 16):(31: 13: 16: 20)$ in a male. Thoracopoda 2 : Third podomere with hairs distally.

Copulatory organ: Basal part large, elliptical; anterior process of rather large, curved tube; posterior one of T-shaped lamella; copulatory tube somewhat long.

(Other characters: cf. generic description).

Material. MO-617, 우, LV (50-26), RV (50-27); MO-618, ㅇ, LV (46-26), RV (46-27); D, 3-V-1977. MO-874, ㅇ, LV (41-22), RV (41-23); MO-874', б7, LV (37-20), RV (37-19); MI. MO-740, o7, LV (38-19), RV (38-20), HSB.

Occurrence. Not common, not abundant in rocky shores, but conspicuously abundant in Hosonosu sand bank.

Remarks. Specimens in the Inland Sea agree with Hanai's (1957). This species resembles $H$. cuneata, but is discriminated from it by the four small central hollows situated rhomboidally.

Sexual dimorphism in the length ratio of podomeres of appendages is thought to be negated. The variation in valve size, however, is great even within females; the smallest (MO-874) being four-fifths the largest (MO-617).

In Kajiyama's (1913) figures of Cytheropteron videns, the copulatory organ (fig. 24) is thought to be of $H$. cuneata, though the carapace (fig. 19) is that of H. kajivamai without doubt.

\section{Hemicytherura tricarinata Hanai, 1957}

(Figs. 1e, f, 2i-1, 6)

Hemicytherura tricarinata Hanai, 1957, p. 25, Pl. 2, figs. 3a, b, Japan (Kumamoto Pref.); Ishizaki, 1968, p. 20, Pl. 4, fig. 13, Japan (Kochi Pref.); Hanai et al., 1977, p. 55.

Description. Valves small, thick, slightly asymmetric. Left valve ovate; greatest height at anterior fourth. Dorsal margin gently arched, gradually descending backwards. Anterior margin obliquely rounded, without denticles. Posterior margin broadly protruding to be caudal process; the extremity at half height; upper half convex, lower half straight. Ventral margin nearly straight. Right valve slightly higher than the left, devoid of dorsal hump, resembling it.

Male remarkably smaller and rather lower than female.

Surface reticulated, and also adorned with ridges; longitudinal ridge prominent, from mid-anterior margin through centre toward caudal process; partially transversal 

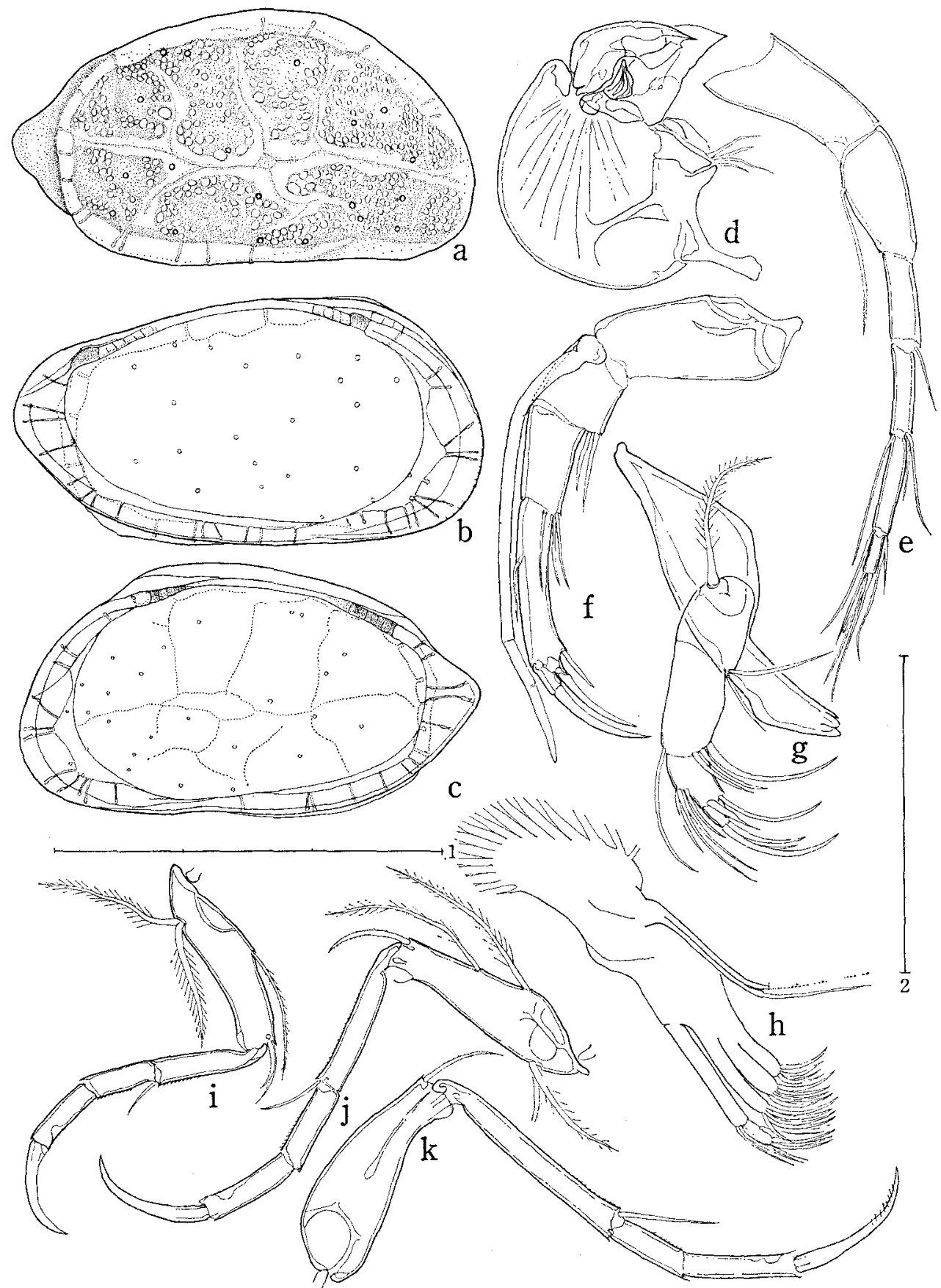

Fig. 6. Hemicytherura tricarinata.

$\mathrm{a}-\mathrm{c}, \mathrm{e}-\mathrm{k}$, 우 (MO-879'); d, oํ (MO-879).

a, right valve (outside); b, left valve; $c$, right valve; $d$, copulatory organ; e, antennula; f, antenna; $\mathrm{g}$, mandible; $\mathrm{h}$, maxillula; $\mathrm{i}$, maxilla; $\mathrm{j}$, thoracopoda 1 ; $\mathrm{k}$, thoracopoda 2.

Scale: $1(=0.3 \mathrm{~mm})$ for $\mathrm{a}-\mathrm{c} ; 2(=0.1 \mathrm{~mm})$ for $\mathrm{d}-\mathrm{k}$. 
ridges five: three at upper half, two at lower half; dorsal marginal ridge less prominent, along dorsal margin; anterior one sinuating, along anterior margin; posterior one curving, from postero-dorsal margin down to postero-ventral margin, apart from posterior end; ventral one along ventral margin.

Infold moderate in width; vestibule somewhat wide anteriorly and postero-ventrally. Radial pore canals moderate in number; tendency to group weak. Normal pore canals scattered. Hingement merodont, of arched type.

Antennula: Length ratio of distal five podomeres 3:2:2:2:1. Antenna: Length ratio of distal four podomeres and claw 14:13:8+14:5:14. Spinneret seta threesegmented at length ratio of $24: 4: 5$; knee at proximal joint.

Mandible and Maxillula: Of hemicytherure type.

Walking legs: Length ratio of distal three podomeres and claws $(32: 19: 21: 32)$ : $(44: 24: 26: 38):(62: 24: 31: 43)$; claws remarkably curved.

Copulatory organ: Basal part rather small; with two flame-like processes and small triangular copulatory tube.

(Other characters: cf. generic description.)

Material. MO-873, o7, LV (34-17), RV (33-17); MO-873', 우, LV (36-19), RV (36-20); MBS, 11-VII-1976. MO-879, ơ , LV (30-15), RV (30-?); MO-879', 우, $\mathrm{LV}$ (36-19), RV (35--20); D, 27-VI-1975. MO-644, 우, LV (40-?), RV (39-21), MBS, 6-V-1977.

Occurrence. Rather common, not abundant.

Remarks. Specimens from the Inland Sea agree well with Hanai's (1957).

This species is discriminated from the allied species by the smaller, triangular valves.

\section{Genus Semicytherura Wagner, 1957}

Type-species: Cythere nigrescens Baird, 1838

Description. Male smaller and/or more elongate than female. Both valves thick or thin, of slight asymmetry. Infold and fused zone conspicuously wide; inner margin and line of concrescence irregularly S-shaped. Radial pore canals small to moderate in number, unbranched, with a few false radial pore canals, tending to be grouped. Normal pore canals a few, scattered. Hingement merodont, of arched type (Hanai, 1957). Adductor muscle scars four in vertical row, with one anterior scar.

Antennula: Of six podomeres. First podomere without seta. Second podomere with seta postero-medially. Third podomere with seta antero-distally. Fourth, fifth podomere with two setae antero-distally, one seta postero-distally, respectively. Sixth podomere with three setae and sense club distally.

Antenna: Of five podomeres. First podomere without seta. Second podomere tumid, with two setae postero-distally. Third podomere tapering, with two setae postero-distally. Fourth podomere long, with respective one seta proximally, posterodistally, and on antero-medial setiferous ledge. Fifth podomere small, with two claws; anterior claw slightly stronger than the posterior in general. Spinneret seta three- 
or four-segmented, knee at penultimate joint; penultimate segment prominently small.

Mandible: Coxa rather large. Palp four-segmented. First podomere of palp with seta postero-distally, and with exopodite of one large plumose seta. Second podomere with one seta antero-distally, three setae postero-distally. Third podomere with four setae antero-medially, two setae postero-distally, one stout seta distally. Fourth podomere with three stout setae distally.

Maxillula: Branchial plate with about 15 feather-like setae, two vibratory setae of unequal length, upper one rudimentary. Palp of two podomeres; proximal one long, with four setae antero-distally; distal one rather small, with three setae distally, one seta postero-medially. Outer, middle, inner masticatory lobe provided with six, six, four setae distally, respectively.

Walking legs: Of four podomeres; protopodites having setal formula $(1,2,2)$, $(1+1,1,1),(0,1,0)$ or $(1,2,1),(1+1,1,0),(0,1,0)$; second podomere with stea anterodistally; claw rather large.

Copulatory organ: Basal part large, with two or three processes of various shapes and long spiral copulatory tube.

(This generic description is mostly based on data obtained from Japanese species.)

Remarks. There are two types in Semicytherura: thick and thin carapace types, as Hanai (1957) has indicated. These types differ also in the setal formula of walking legs. They are, therefore, named henryhowei-group and miurensis-group, and comparatively examined, together with Hemicytherura.

\begin{tabular}{|c|c|c|c|}
\hline & \multirow{2}{*}{ Hemicytherura } & \multicolumn{2}{|c|}{ Semicytherura } \\
\hline & & henryhowei-group & miurensis-group \\
\hline Valves & thick & thick & thin \\
\hline Asymmetry of valves & great & \multicolumn{2}{|l|}{ slight } \\
\hline Width of infold & moderate & \multicolumn{2}{|c|}{ remarkably broad } \\
\hline $\begin{array}{l}\text { Penultimate segment } \\
\text { of spinneret seta }\end{array}$ & rather long & \multicolumn{2}{|l|}{ short } \\
\hline $\begin{array}{l}\text { Vibratory setae of } \\
\text { maxillula }\end{array}$ & of equal length & \multicolumn{2}{|c|}{$\begin{array}{l}\text { of unequal length } \\
\text { (upper one rudimentary) }\end{array}$} \\
\hline $\begin{array}{l}\text { Setal formula } \\
\text { maxilla } \\
\text { thoracopoda } 1 \\
\text { thoracopoda } 2\end{array}$ & $\begin{array}{l}(1,2,2) \\
(1+1,1,0) \\
(0,1,0)\end{array}$ & $\begin{array}{l}(1,2,2) \\
(1+1,1,1) \\
(0,1,0)\end{array}$ & $\begin{array}{l}(1,2,1) \\
(1+1,1,0) \\
(0,1,0)\end{array}$ \\
\hline Copulatory tube & small, short & \multicolumn{2}{|c|}{ long, spiral } \\
\hline
\end{tabular}

\section{(henryhowei-group)}

4. Semicytherura henryhowei Hanai et Ikeya, 1977

(Figs. 1g, h, 3a-c, 7)

Cytherura quadrata Hanai, 1957, p. 20, Pl. 3, figs. 1a, b, text-figs. 2a, b, Japan (Kanagawa Pref.).

Semicytherura quadrata, Hanai, 1961, p. 358, text-fig. 2a, b; Ishizaki, 1966, p. 141, Pl. 18, fig. 18, Japan

(Miyagi Pref., Miocene); -—, 1968, p. 20, P1. 4, figs. 11, 12; Japan (Kochi Pref.); ——, 1971, p. 81, Pl. 3, Fig. 9, Japan (Aomori Pref.). 
Semicytherura henryhowei, Hanai et Ikeya, 1977, p. 56.

Not Cytherura quadrata Norman, 1869.

Description. Valves thick, box-shaped; asymmetry not so conspicuous.

Left valve oblong in lateral view; greatest height at anterior fourth. Dorsal margin nearly straight, gently descending backwards. Anterior margin obliquely and broadly rounded, with about four tubercles; upper half forming angle with the dorsal. Posterior margin occupied with caudal process; upper and lower thirds nearly straight, almost symmetrical; middle third truncate. Right valve with small dorsal hump; therefore slightly higher than the left.

Male smaller than, and sub-equal in shape to, female.

Surface covered with a great number of fine pits, and also ornamented with several ridges. Ventral marginal ridge prominent, along ventral margin; dorsal one less prominent, along dorsal margin; anterior one sinuated, sub-peripheral; posterior one from postero-dorsal angle, convexly down to posterior end of ventral ridge. Central ridge from antero-dorsal angle, down to mid-ventral, branching strong ridge forwards at upper third, then parallel to ventral marginal ridge, lastly obliquely upwards to postero-dorsal angle.

Infold and fused zone conspicuously broad anteriorly and posteriorly; anterior fourth and posterior half occupied with them. Radial pore canals moderate in number, with a few false radial pore canals, showing tendency to be grouped; their inner ducts unbranched, slender, often curved. Normal pore canals only a few in number. Adductor muscle scars four in vertical row, with frontal scar. Hingement merodont, of arched type.

Antennula: Stout, even in the most slender podomere or the fifth one, the width a third of length; setae short in general. Second to sixth podomeres having length ratio 19:9:10:9:4. Antenna: Distal four podomeres and claw having length ratio $11: 14$ : $11+11: 4: 11$. One postero-distal seta of second podomere and proximal seta of fourth podomere showing sexual dimorphism, longer in male. Spinneret seta three-segmented at length ratio 47:3:13; middle segment very short; kneeling at proximal joint.

Mandible and Maxillula: Of semicytherure type.

Walking legs: Setal formula $(1,2,2),(1+1,1,1),(0,1,0)$. Length ratio of second to fourth podomeres and claws $(15: 10: 10: 12):(20: 12: 12: 13):(28: 12: 13: 15)$. Thoracopoda 1 : protopodite posteriorly with vestigial seta, in addition to one posterior plumose seta.

Copulatory organ: Rather small; basal part circular; anterior process of oblong lamella; middle one of long, tubular lamella; copulatory tube rather long, spiral, in some specimens remarkably long.

(Other characters: cf. generic description.)

Material. MO-678, ㅇ, LV (41-22), RV (41-22), M. MO-623, ㅇ, LV (43-23), RV (42-23), D, 3-V-1977. MO-772, ð7, LV (37-18), RV (37-18), D, 28-VII-1977. MO-788, જ઼, LV (38-?), RV (37-?), SI.

Occurrence. Common, not abundant, in rocky shores. 
Remarks. Specimens in the Inland Sea agree with Hanai's (1957). This species differs from congeneric species in the oblong, box-shaped carapace.

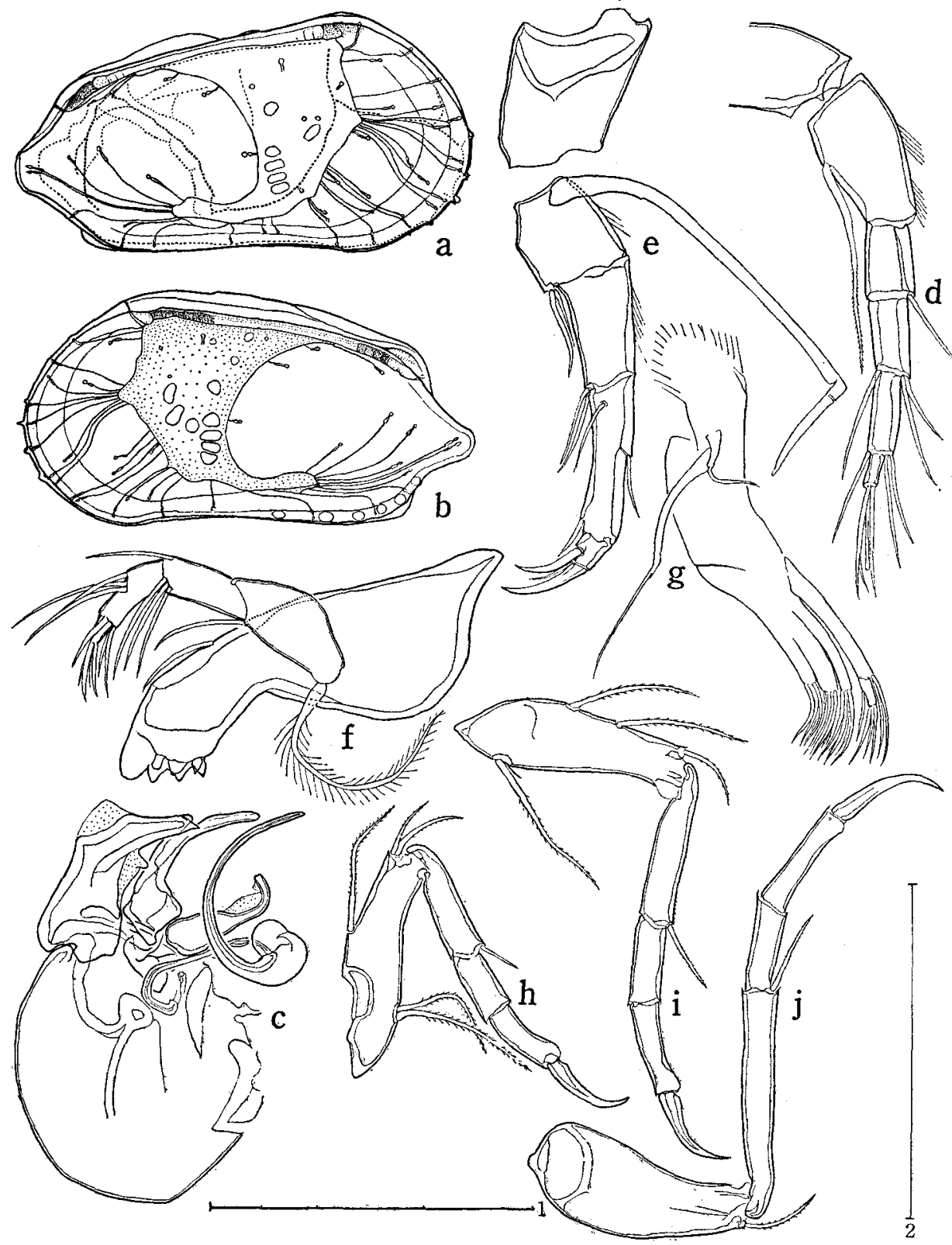

Fig. 7. Semicytherura henryhowei.

$\mathrm{a}, \mathrm{b}$, 우 (MO-623); c, o (MO-870); d-f, oㄱ (MO-766); g-j, ơ (MO-622).

$a$, left valve; $b$, right valve; c, copulatory organ; $d$, antennula; $e$, antenna; $f$, mandible; $g$, maxillula; $h$, maxilla; $i$, thoracopoda $1 ; j$, thoracopoda 2 .

Scale: $1(=0.3 \mathrm{~mm})$ for $\mathrm{a}, \mathrm{b} ; 2(=0.1 \mathrm{~mm})$ for $\mathrm{c}-\mathrm{j}$. 


\section{Semicytherura hiberna sp. nov.}

(Figs. 3d-g, 8, 9)

Description. Valves small, thick, of a little asymmetry. Left valve pentagonally

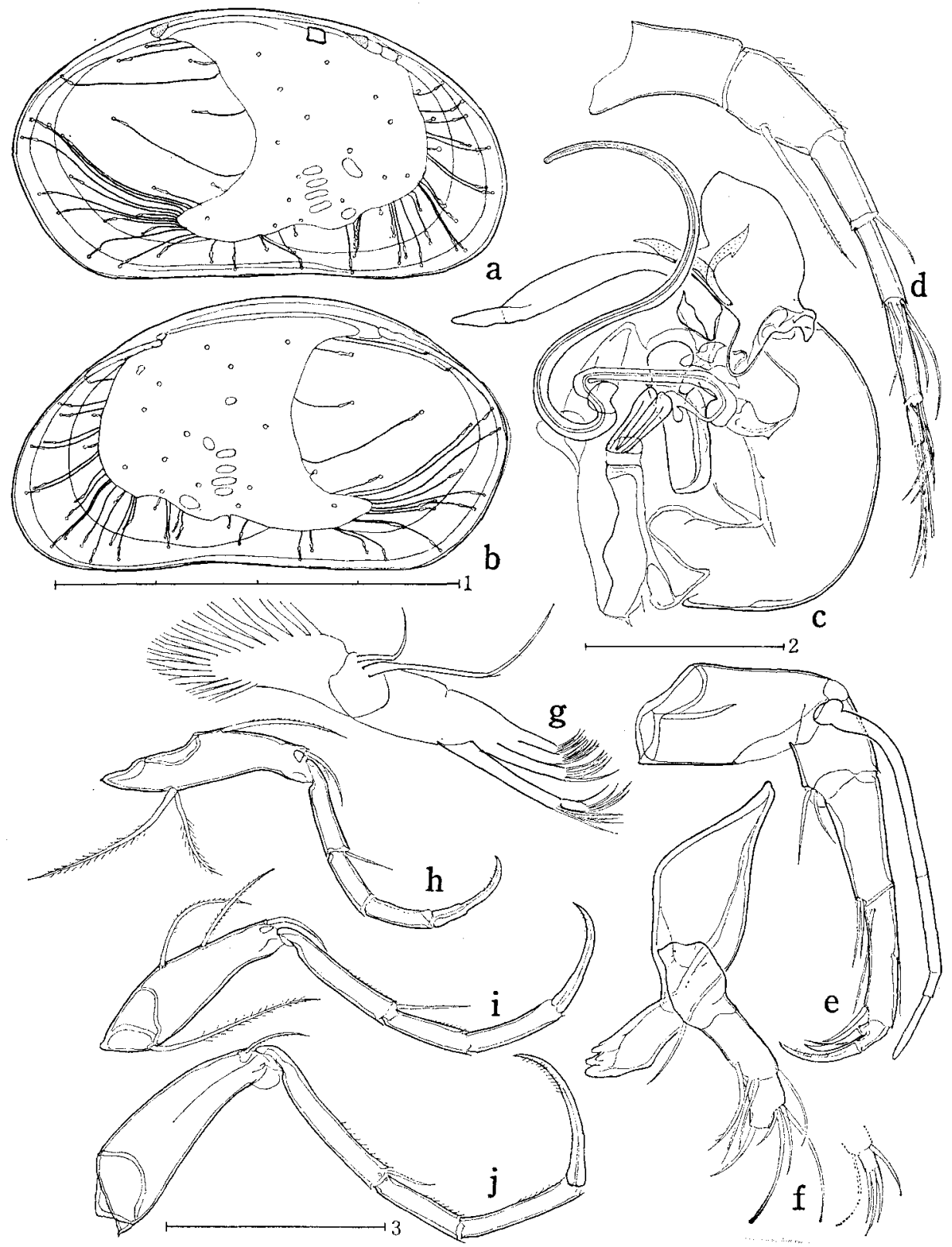

Fig. 8. Semicytherura hiberna.

$\mathrm{a}-\mathrm{j}$, o7 (MO-990). a, left valve; b, right valve; c, copulatory organ; d, antennula; e, antenna; $f$, mandible; $g$, maxillula; $h$, maxilla; $i$, thoracopoda $1 ; j$, thoracopoda 2.

Scale: $1(=0.4 \mathrm{~mm})$ for $a, b ; 2(=0.1 \mathrm{~mm})$ for $c ; 3(=0.1 \mathrm{~mm})$ for $\mathrm{d}-\mathrm{j}$. 
reniform in lateral view; greatest height just behind the middle. Dorsal margin arched evenly. Anterior margin rounded obliquely; the extremity at lower third. Posterior margin distortedly rounded, the extremity at half height. Ventral margin almost straight. Right valve slightly higher than the left, owing to small dorsal hump.

Surface sculptured with a great number of fine pits, and also with weak ridges; anterior and posterior marginal ridges sinuated, sub-peripheral; a few ventral ridges nearly parallel to ventral margin. Inside covered with blackish pigment when alive.

Infold and fused zone remarkably wide: a sixth length anteriorly, half length posteriorly. Radial pore canals rather large in number, showing a tendency to be grouped, unbranched, slender, often curved. False radial pore canals with short inner ducts also present. Normal pore canals scattered. Adductor muscle scars four in vertical row, with one frontal scar and two mandibular scars. Hingement merodont, of arched type.

Antennula: Distal five podomeres having length ratio 35:19:22:24:9. Antenna: Distal four podomeres and claw having length ratio $21: 29: 18+19: 9: 20$; terminal claw haired. Spinneret seta four-segmented at length ratio 57:25:7:18; forming knee at penultimate joint.

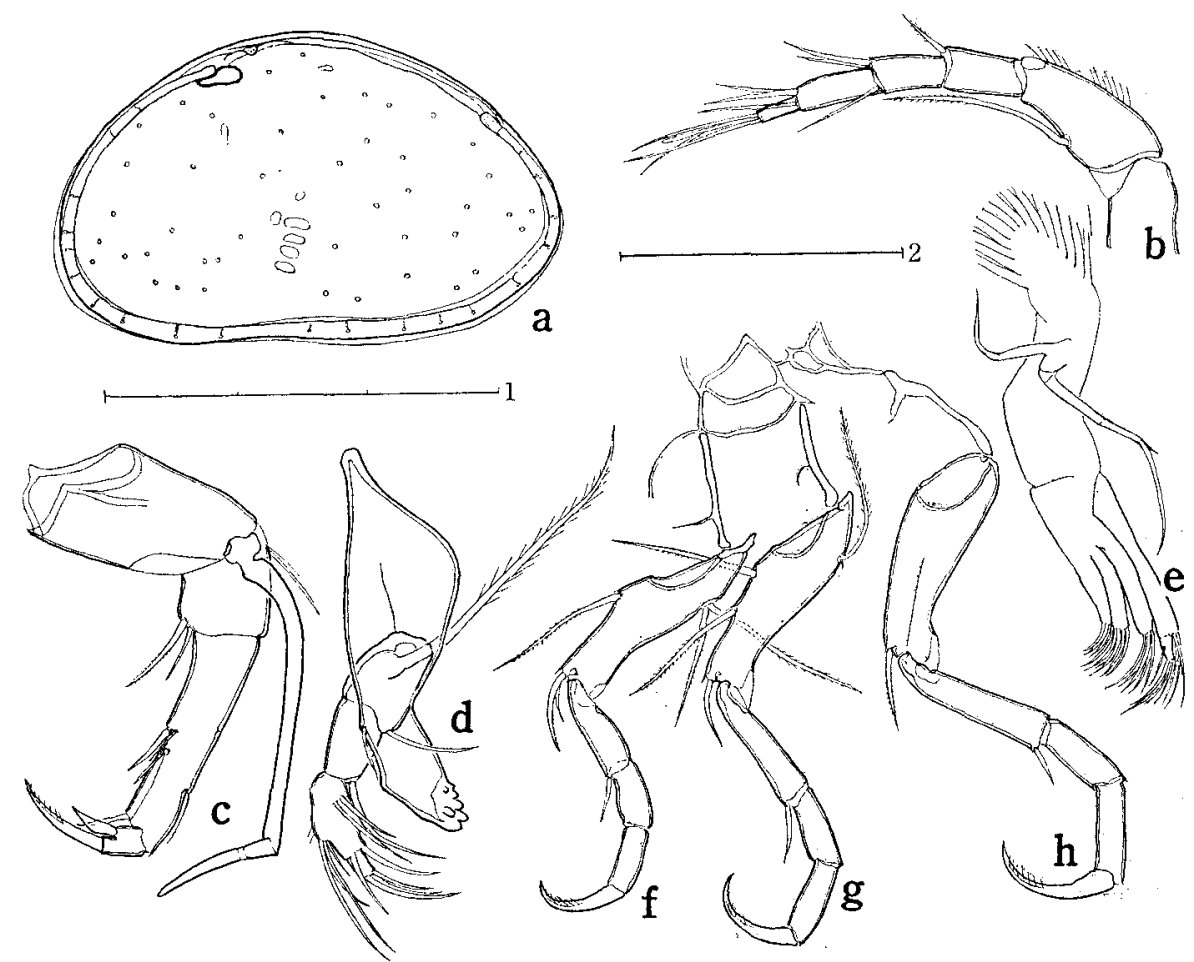

Fig. 9. Semicytherura hiberna.

a-h, A-1 (MO-992). a, right valve; b, antennula; c, antenna; d, mandible; e, maxillula; f, maxilla; $\mathrm{g}$, thoracopoda 1 ; $\mathrm{h}$, thoracopoda 2.

Scale: $1(=0.3 \mathrm{~mm})$ for $\mathrm{a} ; 2(=0.1 \mathrm{~mm})$ for the rest. 
Mandible and Maxillula: Of semicytherure type.

Walking legs: Setal formula of protopodites $(1,2,2),(1+1,1,1),(0,1,0)$; length ratio of second to fourth podomeres and claws $(26: 17: 17: 26):(35: 24: 23: 32):(46: 26$ : $31: 41$ ).

Copulatory organ: Anterior process of mitten-shaped lamella; middle process of long, tongue-like lamella; copulatory tube long, spiral.

(Other characters: cf. generic description.)

Description of $A-1$ instar. Valves without broad infold and fused zone. Antennula stout; number of setae equal to that of adult. Antenna of four podomeres; third and fourth podomeres of adult undivided; subterminal claw broad, seta-like; spinneret seta three-segmented, devoid of proximal joint of adult. Mandible and Maxillula resembling those of adult. Walking legs: Setal formula of the same as in adult; second to fourth podomeres rather stout.

Material. MO-990, or (holotype), LV (49-27), RV (49-27); MO-992, A-1, LV (39-24), RV (39-23); MBS, 12-I-1978.

Occurrence. Rare. Instars found in summer to autumn, adults in winter.

Remarks. The new species is discriminated from allied species in the outline of valves and in rather smooth surface. This species is thought to belong to the henryhowei-group of Semicytherura.

(miurensis-group)

6. Semicytherura mukaishimensis sp. nov.

(Figs. 3h-k, 10)

Description. Valves very thin and semi-transparent, of little asymmetry. Winglike ventral protrusions prominent.

Left valve sub-trapezoidal. Dorsal margin almost straight, parallel to the ventral. Anterior margin obliquely and broadly rounded, the extremity below half, connecting with the dorsal at antero-dorsal angle, with the ventral at antero-ventral swelling. Posterior margin protruding postero-ventrally to make caudal process; upper half long, concave; lower half short, merging into the ventral; the extremity at lower third. Ventral margin nearly straight. Right valve equal to the left in outline. Male more elongate than female.

Surface with a great number of fine pits, and weak ridges; most of ridges longitudinal.

Infold and fused zone conspicuously wide anteriorly and posteriorly; anterior fourth and posterior half occupied with them. Radial pore canals moderate in number, with tendency to be grouped; their inner ducts unbranched, slender, often curved. False radial pore canals a few; normal pore canals also a few. Adductor muscle scars four in vertical row, with one frontal scar. Hingement merodont, of arched type.

Antennula: Distal five podomeres having length ratio $37: 32: 22: 17: 14$, along anterior margins; distal podomere not small; setae rather long. Antenna: Distal four podomeres and claw having length ratio $22: 24+22: 26: 7: 17$, along anterior 


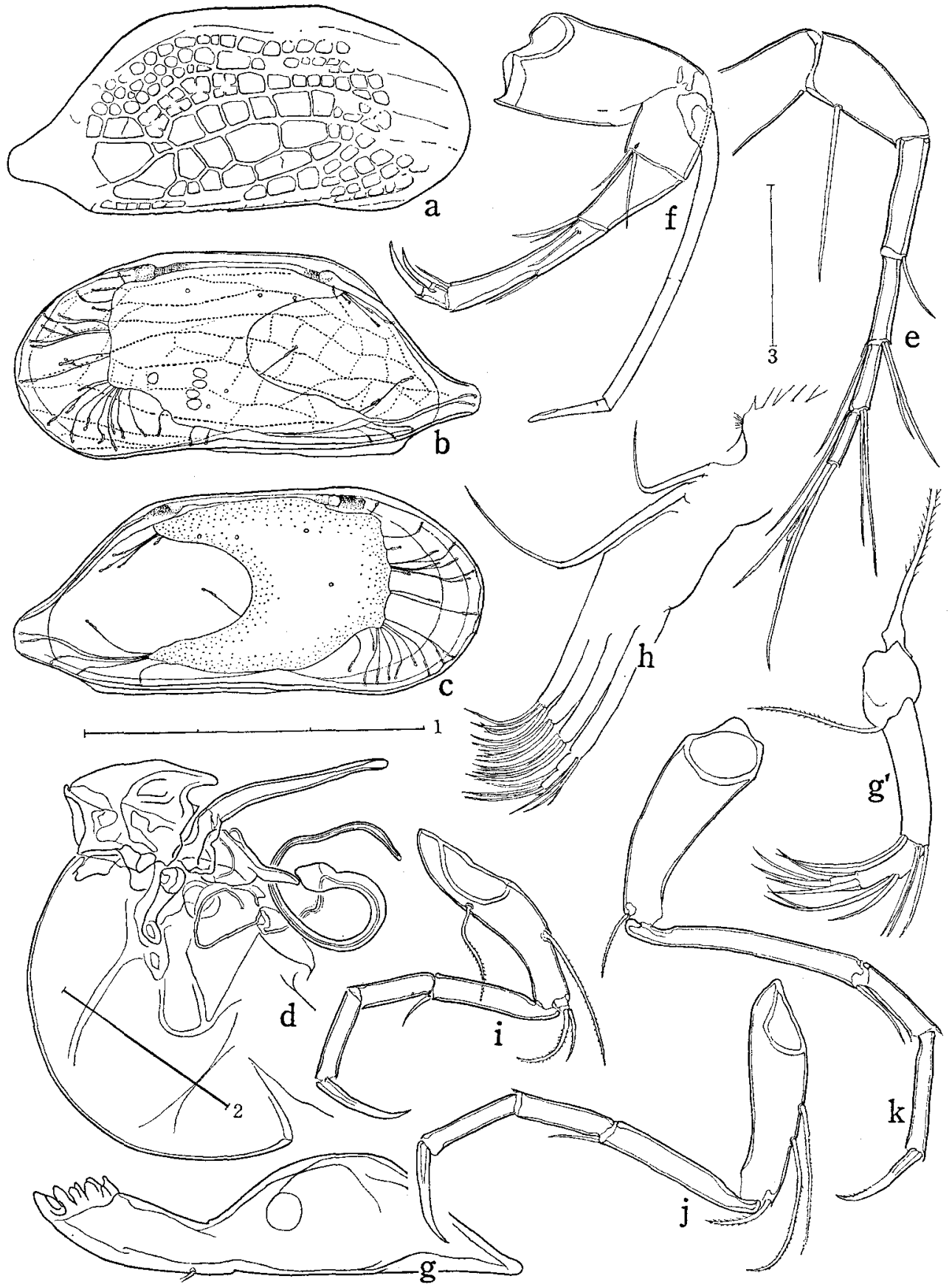

Fig. 10. Semicytherura mukaishimensis.

a-c, 오 (MO-869); d, 구 (MO-562); e-j, g', 우 (MO-573).

a, right valve (outside); b, right valve; c, left valve; d, copulatory organ; e, antennula; $f$, antenna; $\mathrm{g}, \mathrm{g}^{\prime}$, mandible; $\mathrm{h}$, maxillula; $\mathrm{i}$, maxilla; $\mathrm{j}$, thoracopoda $1 ; \mathrm{k}$, thoracopoda 2.

Scale: $1(=0.3 \mathrm{~mm})$ for $\mathrm{a}-\mathrm{c} ; 2(=0.1 \mathrm{~mm})$ for $\mathrm{d} ; 3(=0.05 \mathrm{~mm})$ for $\mathrm{e}-\mathrm{k}, \mathrm{g}^{\prime}$. 
margins. Spinneret seta four-segmented at length ratio of $56: 40: 3: 19$; first and third joints obscure; second joint forming knee.

Mandible: Coxa comparatively large. Second podomere of palp conspicuously long. Maxillula: Setae of masticatory lobes rather long.

Walking legs: Setal formula $(1,2,1),(1+1,1,0),(0,1,0)$. Distal three podomeres and claws having length ratio $(38: 23: 25: 29):(45: 25: 28: 28):(64: 27: 34: 29)$.

Copulatory organ : Basal part ovate; anterior process of sub-quadrangular lamella; middle process of elongate tube; copulatory tube long, spiral.

(Other characters: cf. generic description.)

Material. MO-561, or (holotype), LV (44-18), RV (44-18); MO-869, 오 (allotype), LV (42-18), RV (42-19); MO-564, or (paratype), LV (42-18), RV (42-18); MO-564', or (paratype), C (42-25); MBS, 11-VII-1976.

Occurrence. Not common; in sand banks rather abundant.

Remarks. The new species resembles $S$. miurensis, but differs from it in the caudal process. It is situated at lower third in the new species, while it is at half height in $S$. miurensis.

\section{REFERENCES}

Hanai, T., 1957. Studies on the Ostracoda from Japan, III. Subfamilies Cytherurinae G. W. Müller and Cytheropterinae n. subfam. Jour. Fac. Sci. Univ. Tokyo, (2), 11: 11-36, Pls. 2-4.

- 1961. Studies on the Ostracoda from Japan: Hingement. Ibid., 13: 345-377.

Hanai, T., N. Ikeya, K. Ishizaki, Y. Sekiguchi and M. Yajima, 1977. Checklist of Ostracoda from Japan and its adjacent seas. Bull., Univ. Mus., Univ. Tokyo, (12): 1-119.

Ishizaki, K., 1966. Miocene and Pliocene ostracodes from the Sendai area, Japan. Tohoku Univ., Sci. Rept., (2), 37: 131-163, Pls. 16-19.

- 1968. Ostracodes from Uranouchi Bay, Kochi Prefecture, Japan. Ibid., 40: 1-45, Pls. 1-9.

, 1971. Ostracodes from Aomori Bay, Aomori Prefecture, northeast Honshu, Japan. Ibid., 43: 59-97, Pls. 1-7.

Kajiyama, E., 1913. The Ostracoda of Misaki, Part 3. Zool. Mag. Tokyo (Dobutsugaku-zasshi), 25: 1-16, Pl. 1, (in Japanese).

Müller, G. W., 1894. Die Ostracoden des Golfes von Neapel und der angrenzenden Meeres-abschnitte. Naples Sta. Zool. Fauna Flora Golfes Neapel, Monographie, $31: 1-404$.

Wagner, C.W., 1957. Sur les Ostracodes du Quaternaire Récent des Pays-Bas et leur Utilisation dans l'Étude géologique des Dépots Holocènes. Diss. Univ. de Paris, 1-259. 